\title{
METRIC VARIATION IN Afromeryx AND Libycosaurus (ANTHRACOTHERIIDAE: MAMMALIA) AND ITS UTILITY FOR BIOCHRONOLOGY
}

\author{
Martin PICKFORD \\ Collège de France, UMR 5143 du CNRS, Case postale 38, 8 rue Buffon, \\ 75005 Paris. pickford@mnhn.fr
}

Pickford, M. 2009. Metric variation in Afromeryx and Libycosaurus (Anthracotheriidae: Mammalia) and its utility for biochronology. [Variaciones de tamaño en Afromeryx y Libycosaurus (Anthracotheriidae: Mammalia) y su utilidad para la biocronología.] Revista Española de Paleontología, 24 (2), 107-120. ISSN 0213-6937.

\begin{abstract}
Anthracotheres, like many other mammals, are useful for biochronology, especially those lineages that increased in dimensions with the passage of geological time. One such lineage comprises the tetracuspidate African anthracotheres of the genera Afromeryx and Libycosaurus, which started out as hog-sized animals in the Early Miocene and ended up larger than hippopotami by the end of the Late Miocene.

In mammal groups with few genera at any one time, such as the Neogene anthracotheres of Africa, not only can dental data yield evidence of geological age, but so can postcranial evidence. In the case of Late Neogene suids, which comprised several contemporaneous genera, dental data is useful for biochronology, but only when morphological and metric data are combined. In such groups, postcranial evidence is not as valuable because it is difficult to determine with confidence to which group such bones belong, save in the case of skeletons associated with teeth, of which there are extremely few in the African fossil record.

In Africa, in contrast, anthracotheres had low diversity throughout the Neogene, with usually three or fewer taxa present at most levels older than 17.5 Ma, and only one after ca $16 \mathrm{Ma}$ to the end of the Late Miocene. Evidence shows that this lineage increased in size throughout its existence, from which it is inferred that knowing the dimensions of an African Middle or Late Miocene anthracothere provides information of a biochronological nature.

The Toros-Menalla (TM) fossil zone in Chad has yielded an impressive sample of Late Miocene anthracotheres that was initially attributed to two species of different sizes (Lihoreau, 2003). The presence of two species in the Chad sample was confirmed by Pickford (2008a, 2008b) who drew out some biochronological information from the sample, showing that the TM sedimentary deposits probably spanned a considerable period of time, from ca $10 \mathrm{Ma}$ to ca $6 \mathrm{Ma}$. Not only does the dental sample show this, but so does the postcranial one. The material was subsequently pooled into a single species by Lebatard et al. (2008) who deduced a much shorter duration of sedimentation for the TM sequence aged ca 7 Ma.

The aim of this contribution is to re-examine the question of variability in the Chad sample of Libycosaurus and to compare it to collections from other African localities in order to determine whether the size differences observed are compatible with a single species (Lebatard et al., 2008) or whether they support the presence of two species in the region (Pickford, 2008a, 2008b). If two taxa occur at Toros-Menalla, then this would have implications for the biochronology of the deposits (Pickford, 2008a, 2008b) whereas if only one highly sexually dimorphic species is present, it would have implications for understanding the ecology of these anthracotheres.
\end{abstract}

Keywords: Miocene, Africa, Anthracotheres, biochronology, metric variation.

\section{RESUMEN}

Los antracoterios, como muchos otros mamíferos, son útiles en biocronología, especialmente aquellos linajes que incrementan sus dimensiones con el paso del tiempo geológico. Uno de estos linajes comprende a los antracoterios africanos tetracuspidados de los géneros Afromeryx y Libycosaurus, que comienzan en el Mioceno Temprano con animales del tamaño de un cerdo y terminan en el Mioceno Final con formas más grandes que los hipopótamos.

En grupos de mamíferos con pocos géneros en cualquier momento, como los antracoterios del Neógeno de África, no sólo los datos dentales puede suministrar evidencias de la edad geológica, sino también lo puede hacer los datos postcraneales. En el caso de los suidos del Neógeno Final, que comprenden varios géneros contemporá- 
neos, los datos dentales son útiles para biochronología, pero sólo cuando los datos morfológicos y métricos se combinan. En esos grupos, la evidencia de información postcraneal no es tan valiosa porque es difícil determinar con certeza a qué grupo pertenecen tales huesos, salvo en el caso de esqueletos asociados con la dentición, lo que sucede raramente en el registro fósil de África.

En contraste, en África, los antracoterios durante el Neógeno tuvieron una diversidad baja, usualmente con tres o menos taxones presentes en la mayoría de los niveles más antiguos de 17,5 Ma, y sólo con uno después de ca. 16 Ma hasta el final del Mioceno tardío. Las evidencias muestran que este linaje incrementó su talla durante su existencia, de lo que podemos inferir que conociendo las dimensiones de un antracoterio del Mioceno Medio o Mioceno Final tendremos información de carácter biocronológico.

El área fosilífera de Toros-Menalla (TM) en el Chad ha suministrado una impresionante muestra de antracoterios del final del Mioceno que fueron inicialmente atribuidos a dos especies de diferentes tallas (Lihoreau, 2003). La presencia de dos especies en la muestra del Chad fue confirmada por Pickford (2008a, 2008b) quién destacó alguna información biocronológica de la muestra, mostrando que los depósitos sedimentarios de TM probablemente abarcaban un periodo de tiempo considerable, desde ca. 10 Ma a 6Ma. No sólo la muestra de dentición muestra esta afirmación, sino también la de material postcraneal. El material fue subsecuentemente agrupado en una única especie por Lebatard et al. (2008), que dedujo una duración mucho más corta para la secuencia sedimentaria de TM datada cerca de los 7 Ma.

El propósito de esta contribución es reexaminar la cuestión de la variabilidad en la muestra de Libycosaurus del Chad y compararlo con las colecciones de otras localidades africanas, para determinar si las diferencias de talla observadas son compatibles con una única especie (Lebatard et al., 2008) o si ellas sostienen la presencia de dos especies en la región (Pickford, 2008a, 2008b). Si existen dos taxones en Toros-Menalla, entonces habría implicaciones para la biocronología de los depósitos (Pickford, 2008a, 2008b) mientras que si sólo hubiese una especie con dimorfismo sexual elevado existirían implicaciones para entender la ecología de estos antracoterios.

Palabras clave: Mioceno, África, anthracoterios, biocronología, variaciones de tamaño.

\section{INTRODUCTION}

African mammals have long been successfully used for determining the ages of sediments from which they were collected (Maglio, 1973; Cooke, 1976, 1978a, 1978b, 1984, 1985; Harris \& White, 1979; Pickford et al., 1997). Pickford (2006a) included the anthracotheres in a general review of African Suiformes, and showed that, at a broad scale, the tetracuspidate lineage Afromeryx-Libycosaurus was useful for biochronology. Subsequent studies based on more comprehensive samples from Gebel Zelten stored at the Natural History Museum, London, the Muséum National d'Histoire Naturelle in Paris, and the Geological Survey of Tunisia, Tunis, reveals that the broad subdivisions of time deduced by Pickford (2006a) can be refined thereby improving the resolution of age determinations.

The species Afromeryx zelteni Pickford, 1991 is known to occur at Ombo, Kenya, in deposits aged ca $16 \mathrm{Ma}$. The type locality of the species, Gebel Zelten, is basal Middle Miocene in age ca 16.5 Ma (Pickford, 1991). The locality of Nementcha, in Algeria, which yielded Libycosaurus algeriensis Ducrocq et al., 2001 is of late Middle Miocene age, ca $14 \mathrm{Ma}$, on the basis of the restricted fauna from the site. Much better known is the extensive Beglia, Tunisia, sample of anthracotheres which is reported to have come from two levels, the so called niveau inférieur and niveau supérieur (Black, 1972; Pickford, 2006b) which are close to the Hipparion datum (ca $11 \mathrm{Ma}$ ) some specimens probably being from the end of the Middle Miocene, while others are from the base of the Late Miocene. The Sahabi fauna which yielded the holotype of Libycosaurus petrocchii Bonarelli, 1947 has traditionally been correlated to the Late Miocene, although some authors considered it to be as young as Pliocene. Pickford (2006a) argued that the Sahabi succession spanned the entire Late Miocene period.

As Pickford (2008a) demonstrated, there has been a great deal of confusion about Libycosaurus petrocchii, not only because it was thought to be a dinosaur by Bonarelli (1947), hence its generic name, but subsequently because its first reviser (Black, 1972) confused the holotype for a much larger specimen (in the meantime the holotype seems to have been lost). Because of this confusion, Black (1972) created a new species for the sample from Beglia on account of its diminutive dimensions when compared with the «false» holotype, unaware that it was in fact similar in size to the real holotype. This history was recounted by Pickford (2008a). This leaves the large Libyan anthracotheres without a species name. Gaziry $(1982,1987)$ described additional specimens from Sahabi, but his way of measuring fossils seems to have been incompatible with the methods used by other researchers, making it difficult to work with his measurements. What emerges from all this, though, is that the Sahabi stratigraphic succession spans a considerable period of time (Pickford, 2008a).

What the above résumé reveals is that the tetracuspidate anthracotheres of Africa increased in dimensions 
from the base of the Middle Miocene until the end of the Late Miocene, and that this trend is of potential utility for biochronology because size increase appears to have been gradual rather than punctuated.

The highly significant collection of anthracotheres from the Djourab Desert, Chad, was described and interpreted by Lihoreau (2003) who concluded that the material belonged to two species which differed in dimensions. For some postcranial elements such as the talus, calcaneum and metapodials, the differences in dimensions of the smallest and largest individuals are of the order of $15 \%$. If there are two taxa in Chad, the means differ by $12-13 \%$ (MC III 13\%, MC IV 15\%, MT III 12.9\%, MT IV 12.3\%).

If the Chad anthracothere material is pooled into a single species (Lebatard et al., 2008), it would imply that the mean body weight of males would have been in the region of 1.6 times as much as that of females. For comparison, hippopotamid females are on average smaller than males, but the difference in mean body weight is not as much as proposed for the Chad anthracotheres if they are pooled into a single species [male hippos 1500-3200 kg, female hippos $1350-2500 \mathrm{~kg}$, male mean is 1.3 times the female mean (Haltenorth \& Diller, 1988)].

Because there are important implications concerning the biochronology (Pickford, 2008a) and palaeoecology of the Toros-Menalla sedimentary succession, it is crucial to re-examine the variability that characterises the anthracotheres collected from there. For this exercise to be meaningful it is necessary to refer to samples of anthracotheres from other localities, in order to determine whether the same, or a similar, degree of variability occurs in those localities as well. The only other sample of Libycosaurus Bonarelli, 1947 that approaches the Chad one in terms of quantity of material is the one from Beglia, Tunisia (Pickford, 2006b). The anthracothere collections from Gebel Zelten, Libya and Ombo, Kenya, are much more restricted, but they are included in this analysis because they provide time depth to the evolution of the Libycosaurus lineage, as concluded by Pickford (1991). Good samples of anthracotheres are also available from the Siwaliks of the Indian Subcontinent (Lihoreau et al., 2004, 2007) and these provide adequate samples for comparison with the Chad material.

\section{BIOSTRATIGRAPHY}

For understanding variability in any fossil sample it is crucial to have knowledge about the sequence and timing of events. The stratigraphy of the tetracuspidate African anthracotheres was provided by Pickford $(1991,2008 \mathrm{a})$ and is extended here in figure 1 .

The Siwalik succession of the Potwar Plateau, Pakistan, has been well mapped and dated (Barry et al., 1980, 2002). The stratigraphic position of the localities that yielded the fossil anthracotheres is shown in figure 2. Each of the three species of Merycopotamus Falconer \& Cautley, 1847 de-

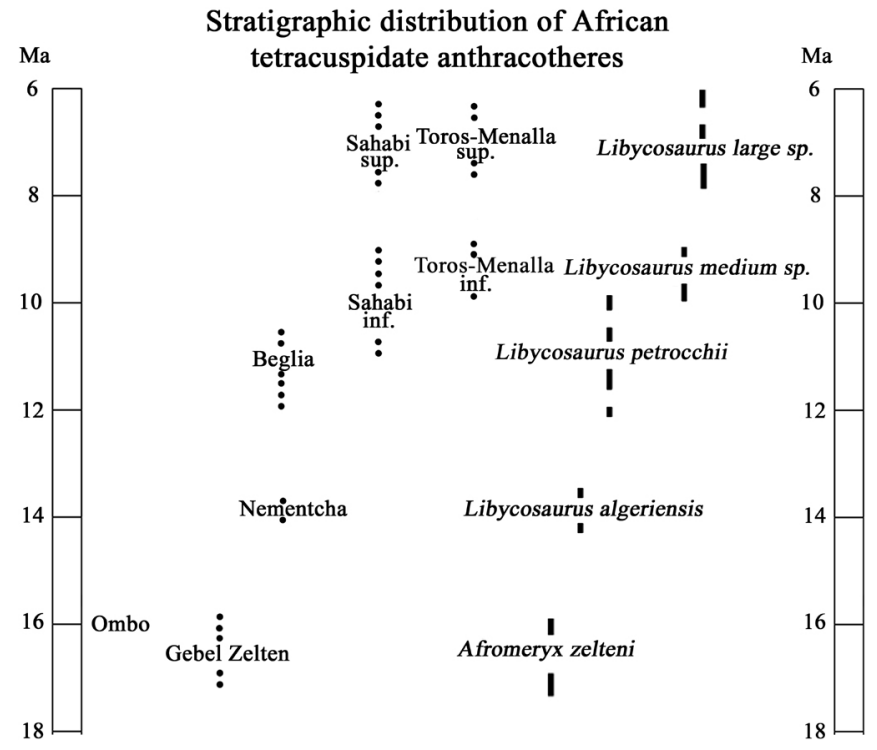

Figure 1. Stratigraphic distribution of African tetracuspidate anthracotheres (figure extended from Pickford, 2008a).

scribed from the region spans an appreciable time period, ca 2.6 million years for Merycopotamus nanus Falconer, 1868, ca 1.7 million years for Merycopotamus medioximus Lihoreau et al., 2004, and ca 1.9 million years for Merycopotamus dissimilis (Falconer \& Cautley, 1836).

\section{DENTAL VARIABILITY IN ANTHRACOTHERES}

\section{INTER-MOLAR PROPORTIONS}

Pickford (2008b) demonstrated that a significant difference between hippopotamids and anthracotheres concerned the dimensions of the first upper molars relative to the second and third ones. In general, anthracothere M1/s are significantly smaller than the M2/s and M3/s (Lihoreau et al., 2004, 2007; Pickford, 2008b) and in homogeneous samples there is no overlap in dimensions of the M1/ relative to $\mathrm{M} 2 /$ or $\mathrm{M} 3 /$.

\section{Indian Subcontinent}

In Merycopotamus medioximus, the slight degree of overlap in dimensions between M1/ and M3/ (Fig. 3) is due to the fact that specimens from various levels have been pooled together. The hypodigm of this species (Lihoreau et al., 2004) came from many stratigraphic levels spanning the period from ca $9 \mathrm{Ma}$ (loc. Y251) to ca $7.6 \mathrm{Ma}$ (loc. Y 408) (Fig. 2). Time averaging of a lineage that was increasing in size with the passage of time is therefore undoubtedly responsible for the overlap in M1/ and M3/ dimensions in $M$. medioximus. The other two species from the Siwaliks show no overlap between the dimensions of M1/ and M3/ and the small degree of overlap between the 


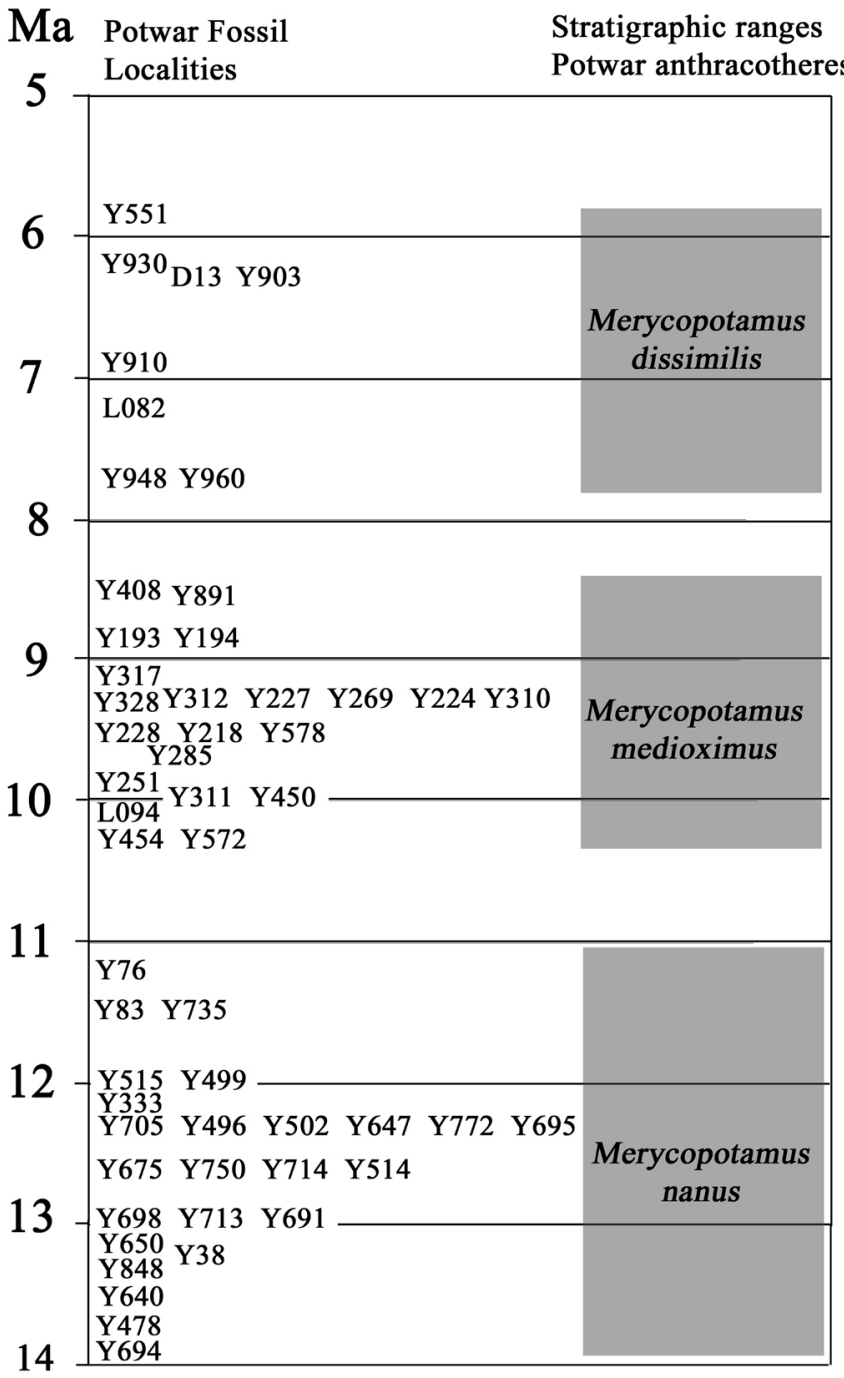

Figure 2. Stratigraphic positions and geochronology of Potwar, Pakistan, anthracotheres (data from Barry et al., 1980, 2002; Lihoreau, 2003; Lihoreau et al., 2004, 2007). Note that all three species of Merycopotamus from the Potwar deposits span lengthy periods of time during which all three species increased in dimensions. Implicit is continuity between species, even though the fossil record has been interpreted as having gaps.

breadths of M1/ and M2/ is probably due to time averaging of a lineage that was increasing in dimensions, albeit, in this case, quite slowly.

\section{Africa}

In the Beglia sample of Libycosaurus petrocchii Bonarelli, 1947 (ex Libycosaurus anisae Black, 1972) there is no overlap in the scatter of breadth dimensions of M1/ relative to M2/ or M3/ (Fig. 4). The same applies to Afromeryx zelteni Pickford, 1991, although the sample from the latter site is small (Fig. 4). In Lihoreau's (2003) initial interpretation of the Chad sample in which he recognised the pres- ence of two species, there is minor overlap in dimensions of M1/ and M2/, but none between M1/ and M3/ (Fig. 4).

In contrast, if Lebatard et al. (2008) are right that there is only one species of anthracothere at Toros-Menalla, then there is significant overlap in the breadth dimensions of M1/, M2/ and M3/ (Figs 5, 6). This would make the Chad sample markedly divergent from the pattern expressed in the Beglia assemblage, which indicates the likely presence of time averaging of a lineage that was increasing in size with the passage of time, and it therefore underscores the fact that the Chad sample was gathered from sediments that accumulated over a lengthy span of time.

In conclusion, the presence of an overlap in breadth measurements of M1/ and M3/ in a pooled Chad sample of anthracotheres, provides sound evidence that it contains a time averaged collection of a lineage that was increasing in dimensions with the passage of time. Conversely, separation of the Chad anthracotheres into two size groups, as was done by Lihoreau (2003) yields a pattern of inter-molar variation that is closer to that of species from other localities, such as Beglia, but with some residual effect of time averaging. This is because the separation between molar dimensions (M1/-M2/, and M1/-M3/) is less in the Chad groups than in the Beglia sample. There can be little doubt that the Chad anthracotheres span a considerable period of time.

Conversely, if the Chad anthracotheres are pooled together into a single species (Lebatard et al., 2008), and the bimodality is interpreted in terms of sexual dimorphism, then it would imply that the average male anthracothere would have weighed about 1.6 times the average female, which would make the Chad anthracotheres extremely sexually bimodal in body size. In hippos, in contrast, males are on average only 1.3 times the weight of females. Additional argument against this interpretation is provided by evidence from other sites in Africa and Asia that have yielded adequate samples of anthracotheres. In none of them does sexual dimorphism approach that postulated for the pooled Chad species.

\section{BIMODALITY OF MOLARS}

Univariate plots of molars of Libycosaurus (Figs 7, 8) reveal that the Chad collection is highly bimodal, with no overlap between the two groups in length measurements of $\mathrm{M} 3 /$, unlike the Beglia assemblage in which the distribution is bimodal with significant overlap between two groups. In breadth measurements the Beglia sample is essentially unimodal, but the Chad one is trimodal for breadth of M3/.

In the lower third molars the Beglia sample is unimodal whereas the Chad one is trimodal, suggesting the presence of at least two taxa in the deposits.

\section{DISCUSSION}

The published data on the M1/ and M2/ of Libycosaurus from Chad does not permit assessment of the role of sexual dimorphism in the sample, because this is usually only 


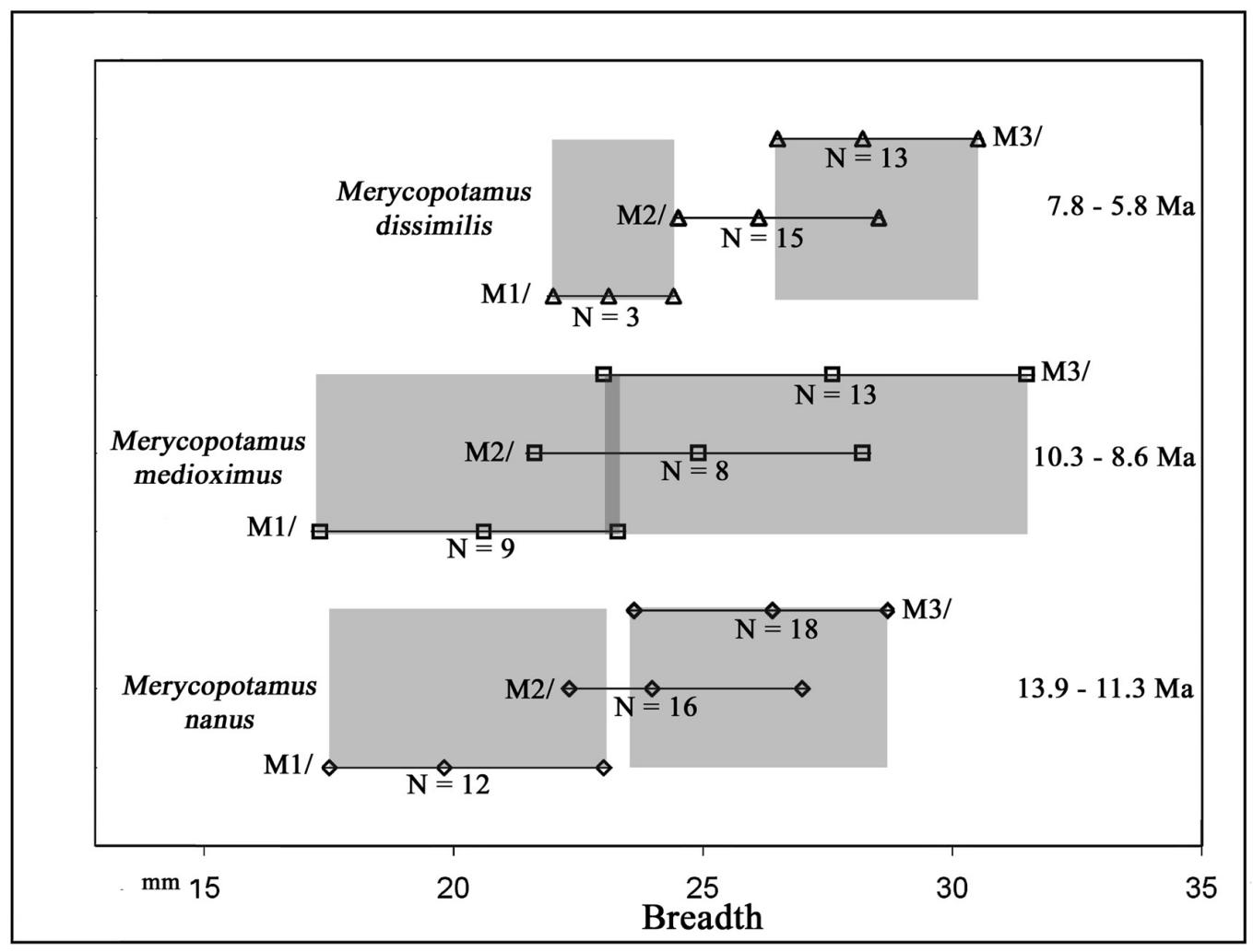

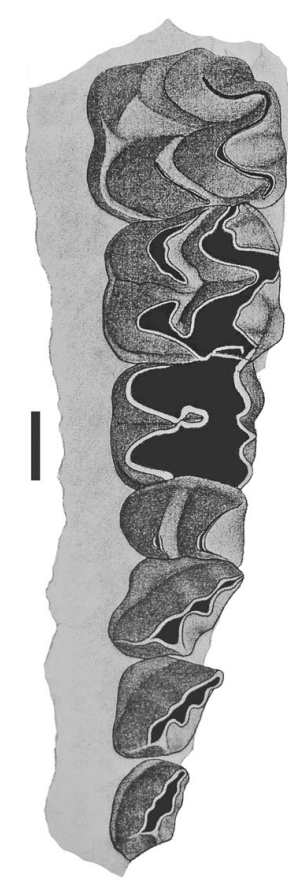

Merycopotamus nanus right maxilla P1/-M3/

Figure 3. Inter-molar proportions among three species of Merycopotamus Falconer \& Cautley, 1847 from the Siwaliks of Pakistan and India. In only one species is there any overlap in the dimensions of M1/ and M3/ (shaded) and in that case (M. medioximus) the overlap is minor. In two of the species (M. nanus and M. medioximus) there is slight overlap in dimensions of M1/ and M2/, but there is none in the third species (M. dissimilis). Data from Lihoreau et al. (2004, 2007). The number of individuals is provided (Image of cheek tooth row is modified from Lihoreau et al., 2007).

\section{Afromeryx and Libycosaurus upper molars}

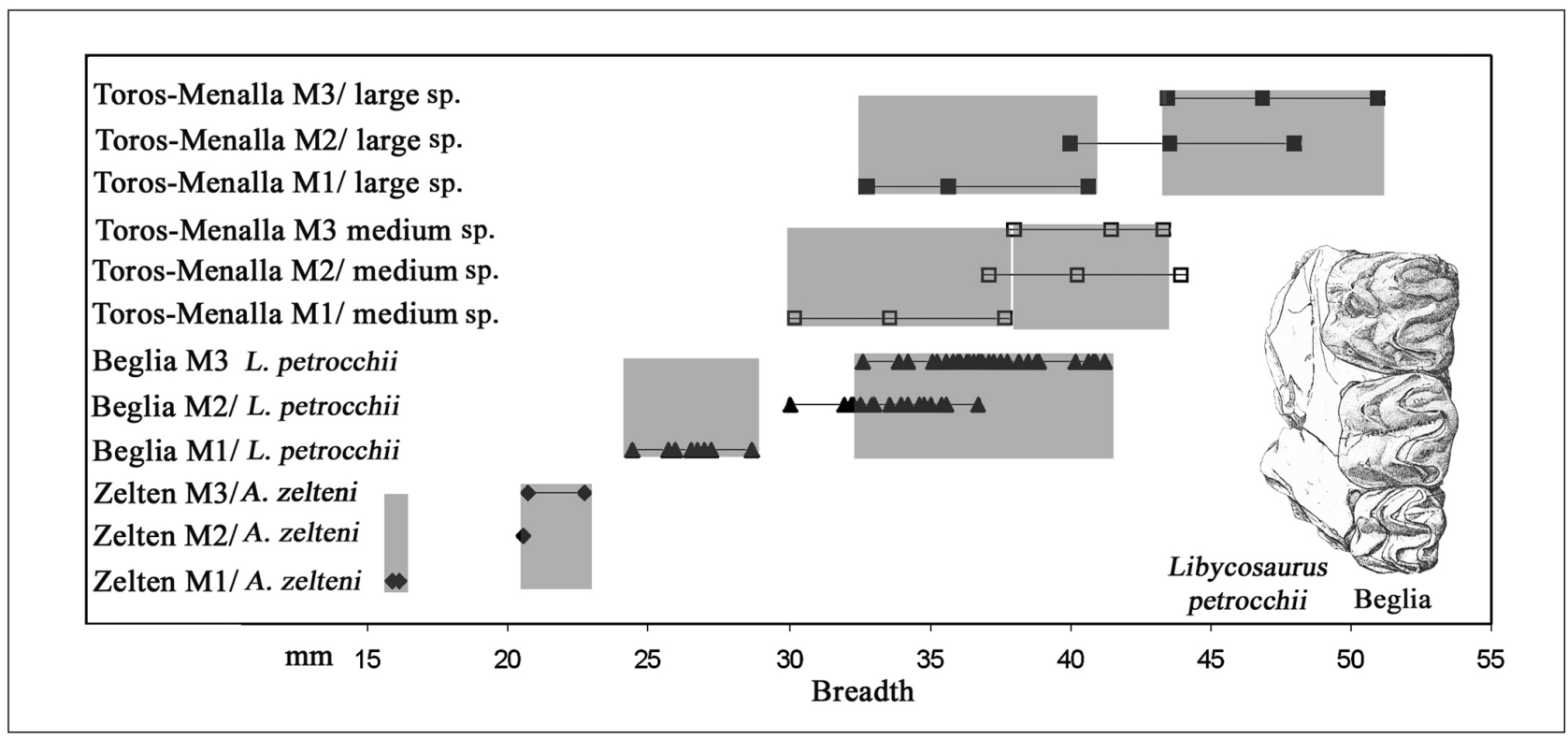

Figure 4. Molar size relations in Libycosaurus and Afromeryx. In Zelten and Beglia species there is no overlap in breadth dimensions between M1/ (shaded) and M2/, or between M1/ and M3/ (shaded). If there are two species at Toros-Menalla as originally concluded by Lihoreau (2003), then there is only minor overlap between M1/ and M2/ and none between M1/ and M3/. Toros-Menalla measurements represent the mean, minimum and maximum measurements from Lihoreau (2003); other measurements from Pickford (1991, 2006b). 


\section{Libycosaurus upper molars}

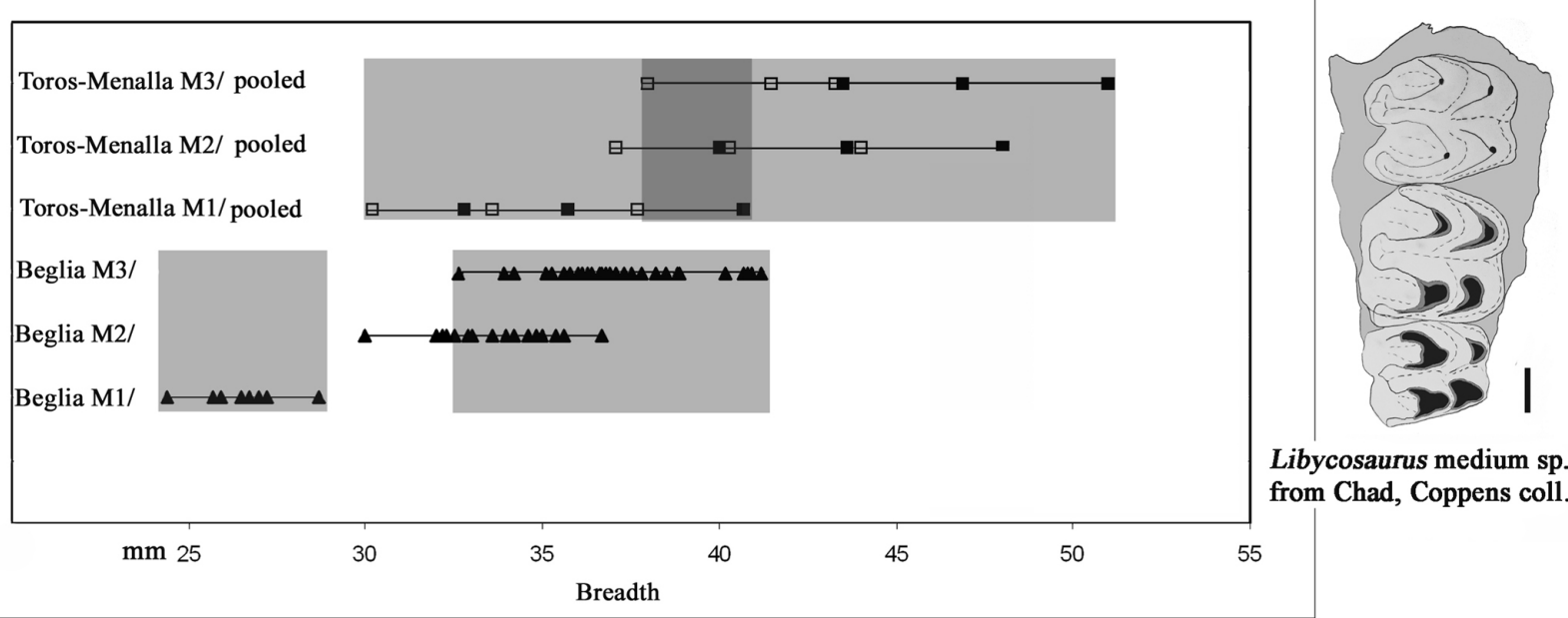

Figure 5. If the Toros-Menalla Libycosaurus sample is treated as a single species (Lebatard et al., 2008), then there is extensive overlap between the breadth dimension of M1/ (shaded) and those of M2/ and M3/ (shaded). Toros-Menalla measurements represent the mean, minimum and maximum measurements from Lihoreau (2003); other measurements from Pickford (1991, 2006b). Scale of left maxilla from Chad containing M1/-M3/: $1 \mathrm{~cm}$.

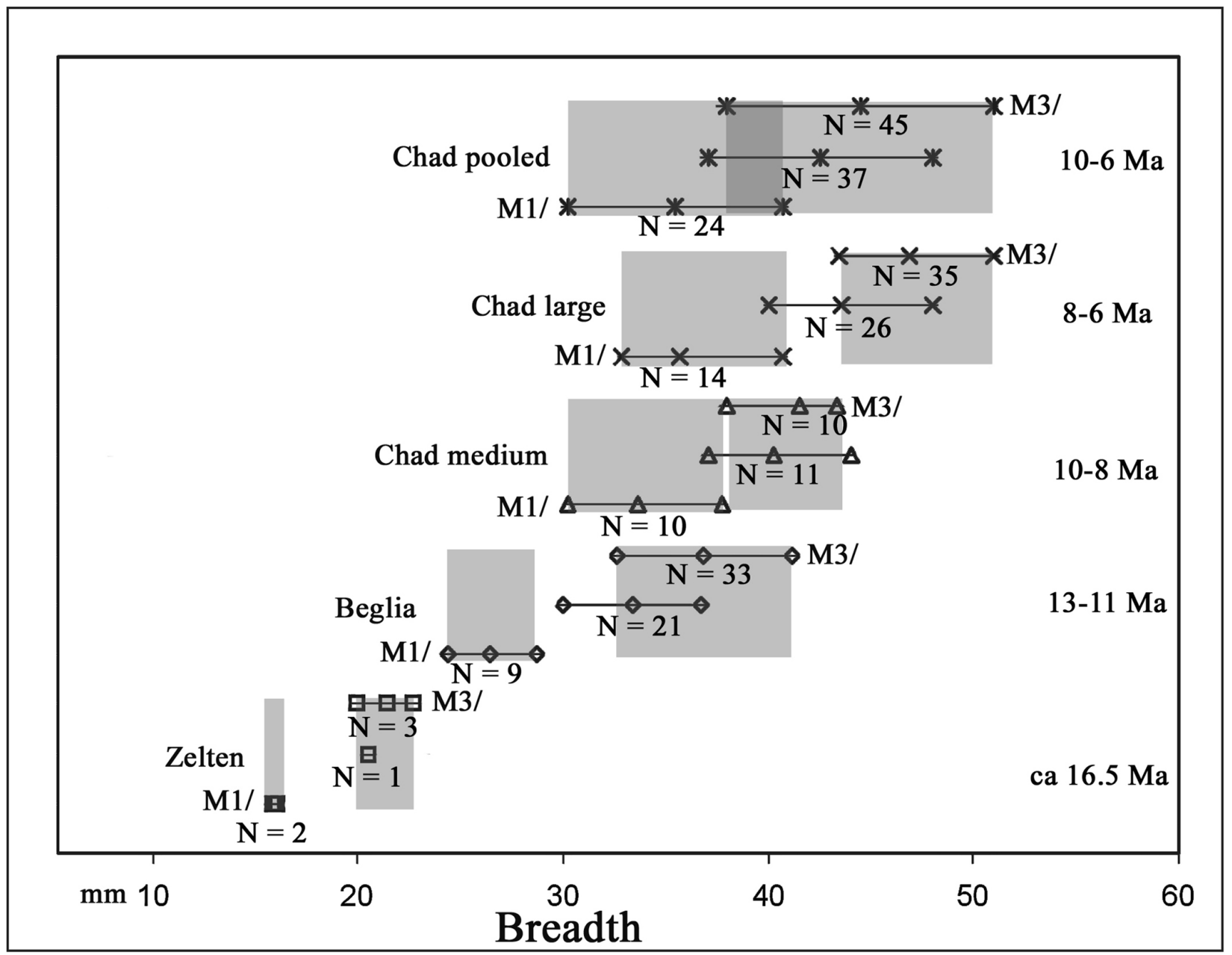

Figure 6. Relative breadth dimensions of M1/, M2/ and M3/ in African Miocene anthracotheres. Note the absence of overlap in measurements of M1/ (shaded) and M3/ (shaded) in all species except the pooled sample from Chad. Number of individuals is provided. 

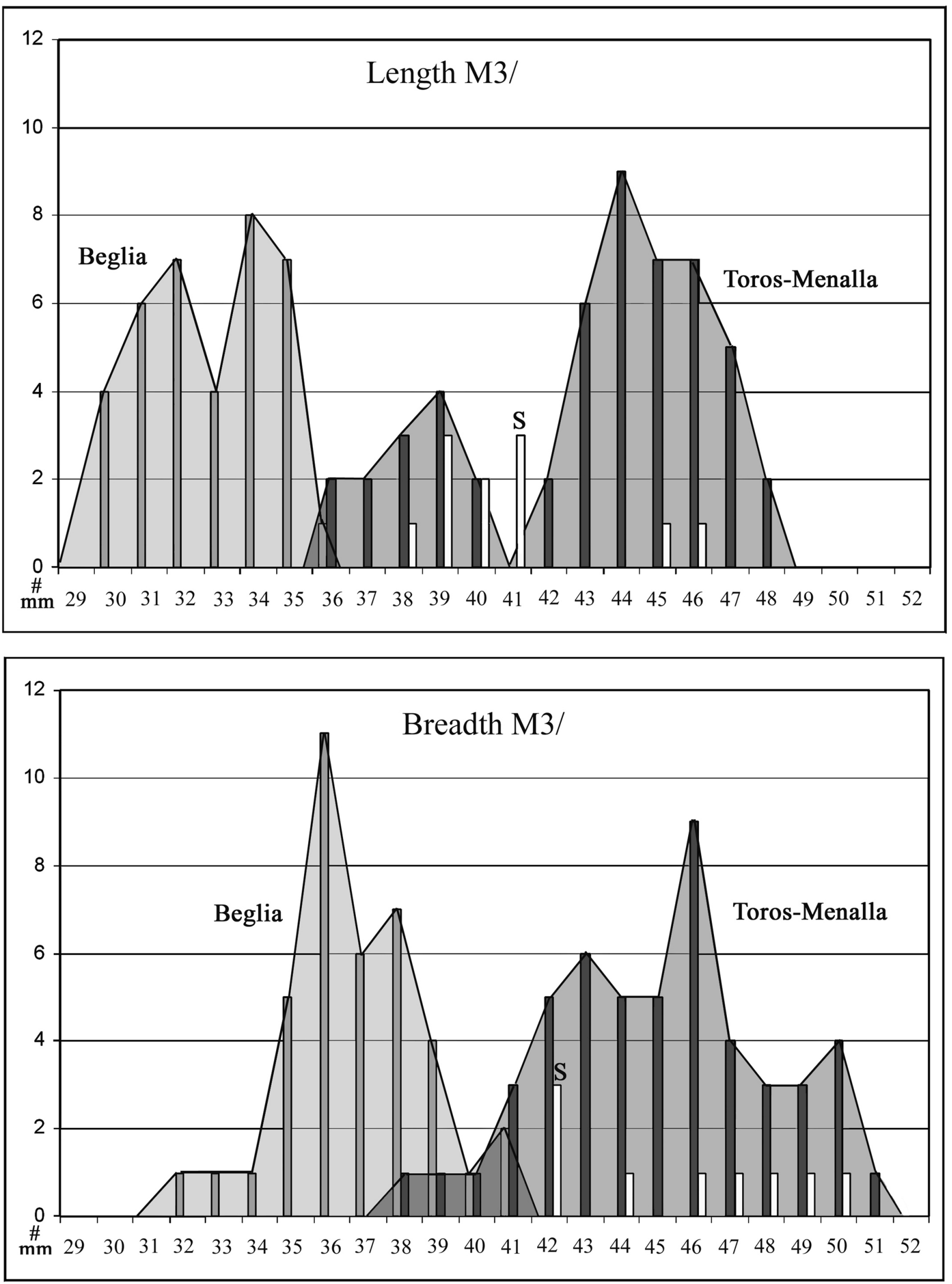

Figure 7. Histogram of length and breadth of M3/s of Libycosaurus species. S - Sahabi. Data from Black (1972), Gaziry (1987), Lihoreau (2003), Pickford (2006b) and Pavlakis \& Boaz (2008); x- axis: dimensions of teeth; y-axis: quantity of specimens. 


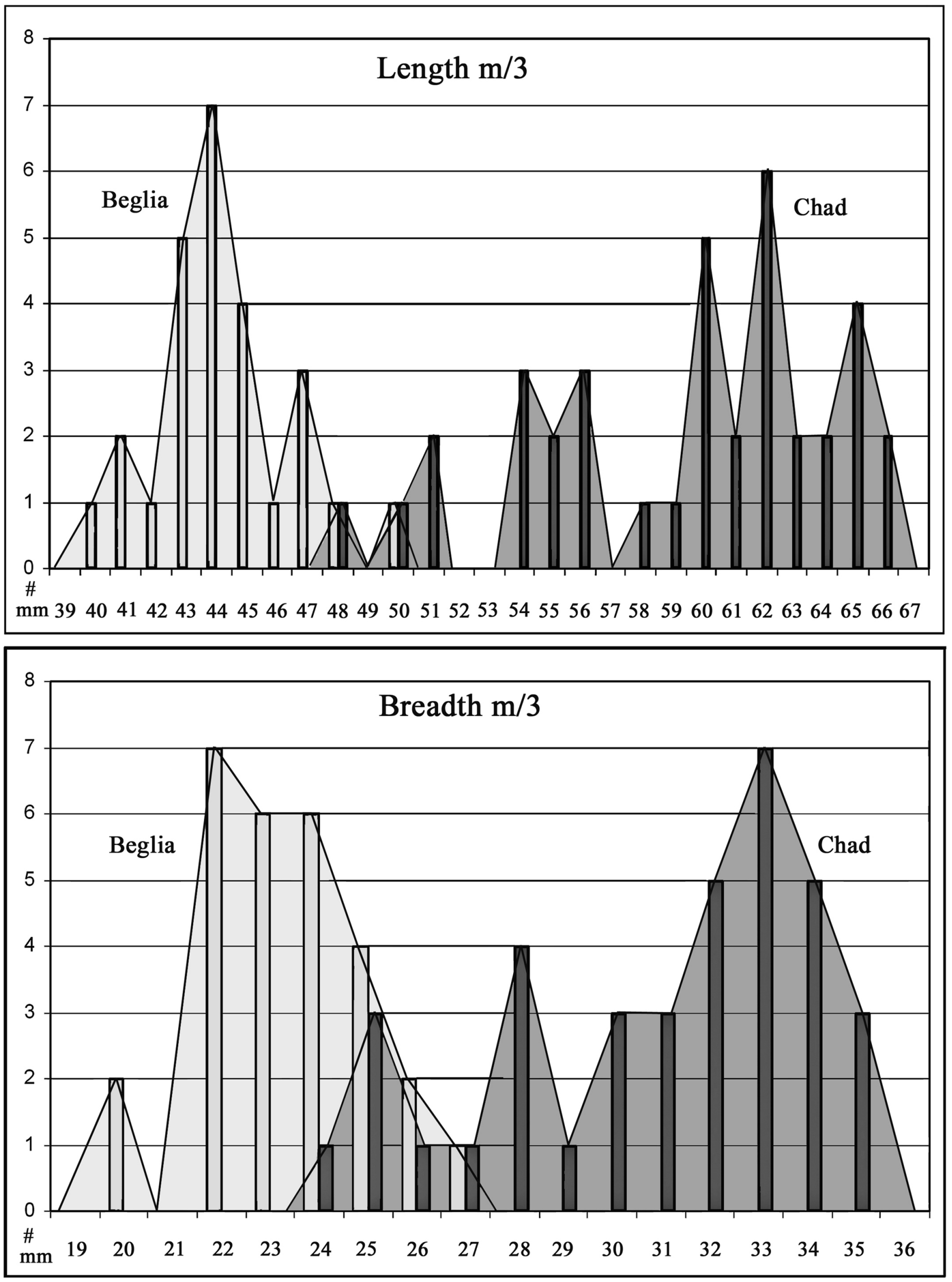

Figure 8. Histogram of length and breadth measurements m/3 of Libycosaurus species. Data from Black (1972), Gaziry (1987), Lihoreau (2003) and Pickford (2006b); x- axis: dimensions of teeth; y-axis: quantity of specimens. 
appreciated in bivariate scatter plots. Tables of mean, min. and max. with standard deviations, such as were published by Lihoreau (2003; Lihoreau et al., 2004, 2007) are not endowed with this kind of information. However, Lihoreau (2003) did publish bivariate plots of M3/, m/3 and some postcranial elements, which demonstrate clearly that the Chad anthracotheres are bimodal, as he concluded. The bimodality is not due to sexual dimorphism because none of the other samples of tetracuspidate anthracotheres from Africa show a comparable degree of variation, neither do the samples of Merycopotamus from the Indian Subcontinent. Such a bimodal pattern of variation in bivariate plots in which the two groups are well separated from each other (Figs 9, 10) provides sound evidence not only of the presence of two taxa in the Chad sample but also that neither of them belongs to the same species as the Beglia sample. The next section of this paper, therefore, examines in detail the metric variation in the postcranial skeleton of tetracuspidate anthracotheres.

\section{POSTCRANIAL VARIABILITY}

Examination of samples of anthracothere postcranial bones from various localities in Africa and Asia, provides evi- dence about the range of metric variation in these mammals (Fig. 9). The most useful measurements to analyse are those related to weight-bearing bones near the ends of the limbs. The talus and the axial metapodials are the most abundantly preserved, and thus the most useful. For the purposes of bivariate analysis we concentrate on the medio-lateral breadth and length of these bones.

\section{Talus}

Bivariate plots of African anthracothere tali reveal a consistent pattern (Fig. 9). In the Beglia sample the difference between the smallest and largest talus is $11.6 \%$ and in Afromeryx zelteni Pickford, 1991 from Libya and Kenya, the difference is $11.2 \%$. Treated as separate species the tali of the two bimodal groups of Chad anthracotheres differ by $11.5 \%$ and $11.4 \%$, whereas if the sample is pooled into a single species, the variation in the dimensions of tali rises to $13.8 \%$.

\section{Metapodials}

The metapodials of anthracotheres from Chad are important in that they reveal major variation in dimensions (Table 1) that when pooled together fall beyond what would be

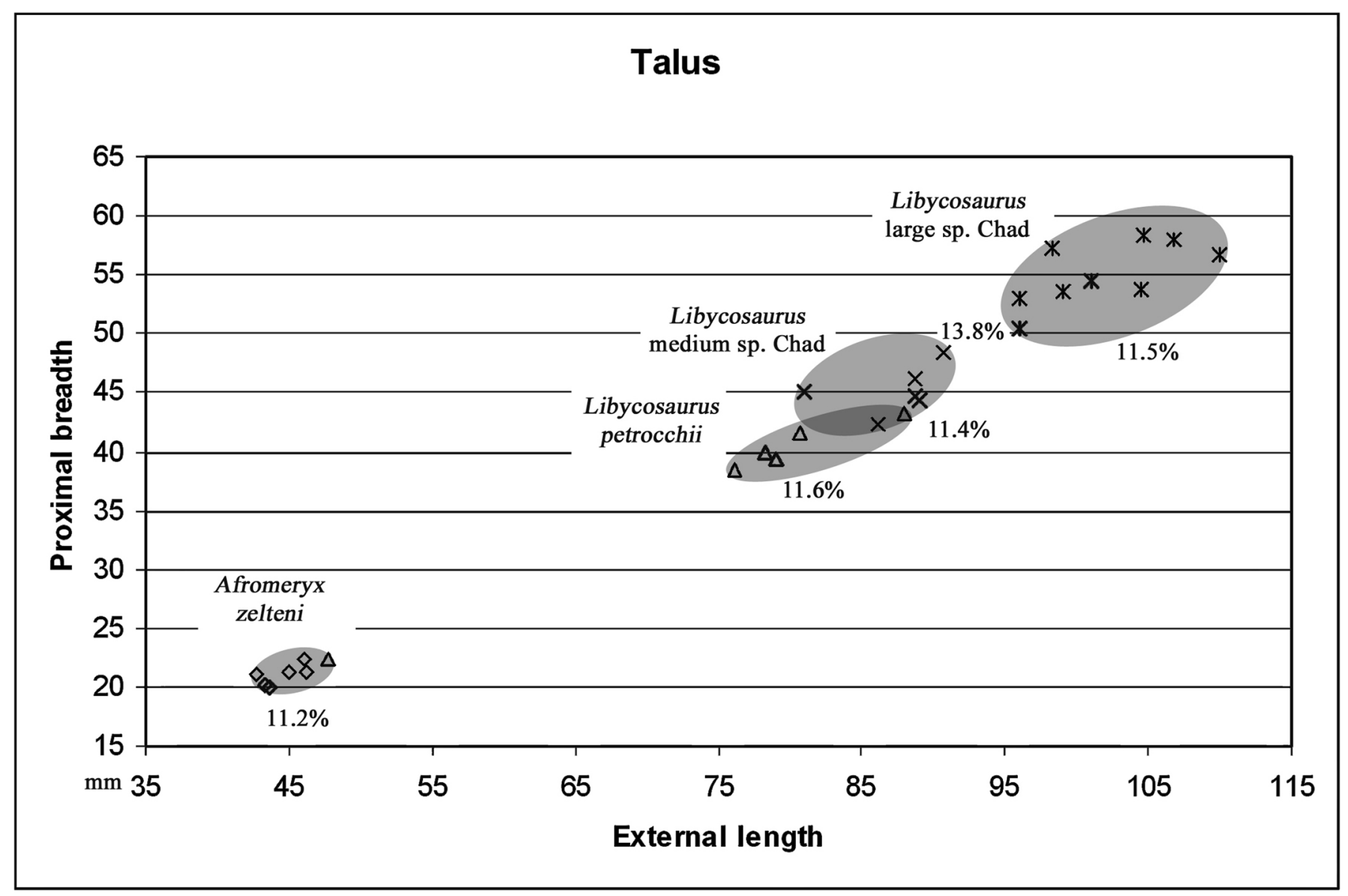

Figure 9. Bivariate length-breadth plot of Libycosaurus tali from Toros-Menalla compared with those of anthracotheres from other fossil localities in Africa. Data from Pickford (1991, 2005, 2007) and Lihoreau (2003); \% = range of variation - $\max / \mathrm{min} \%$. 


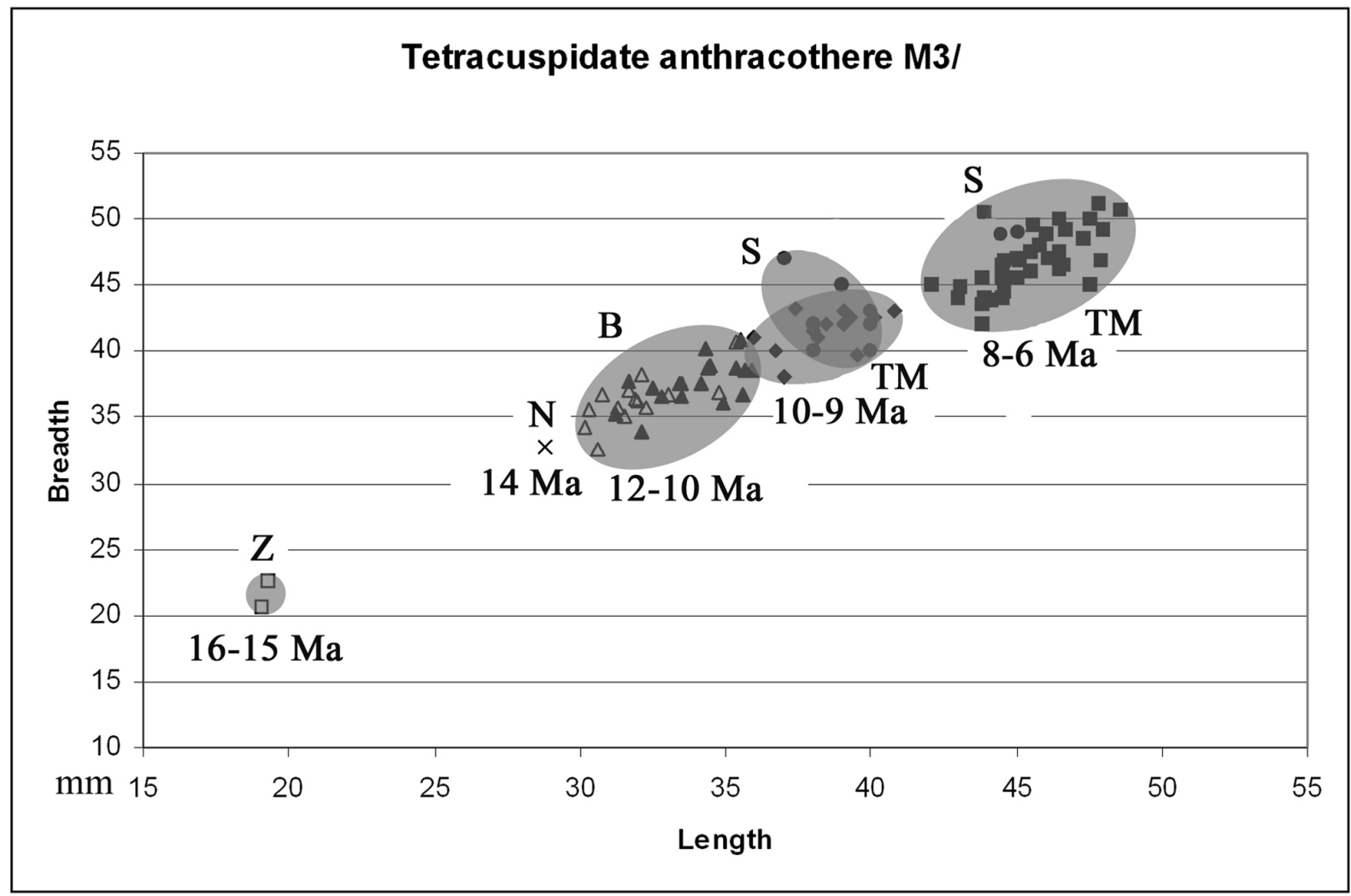

Tetracuspidate anthracothere $\mathrm{m} / 3$

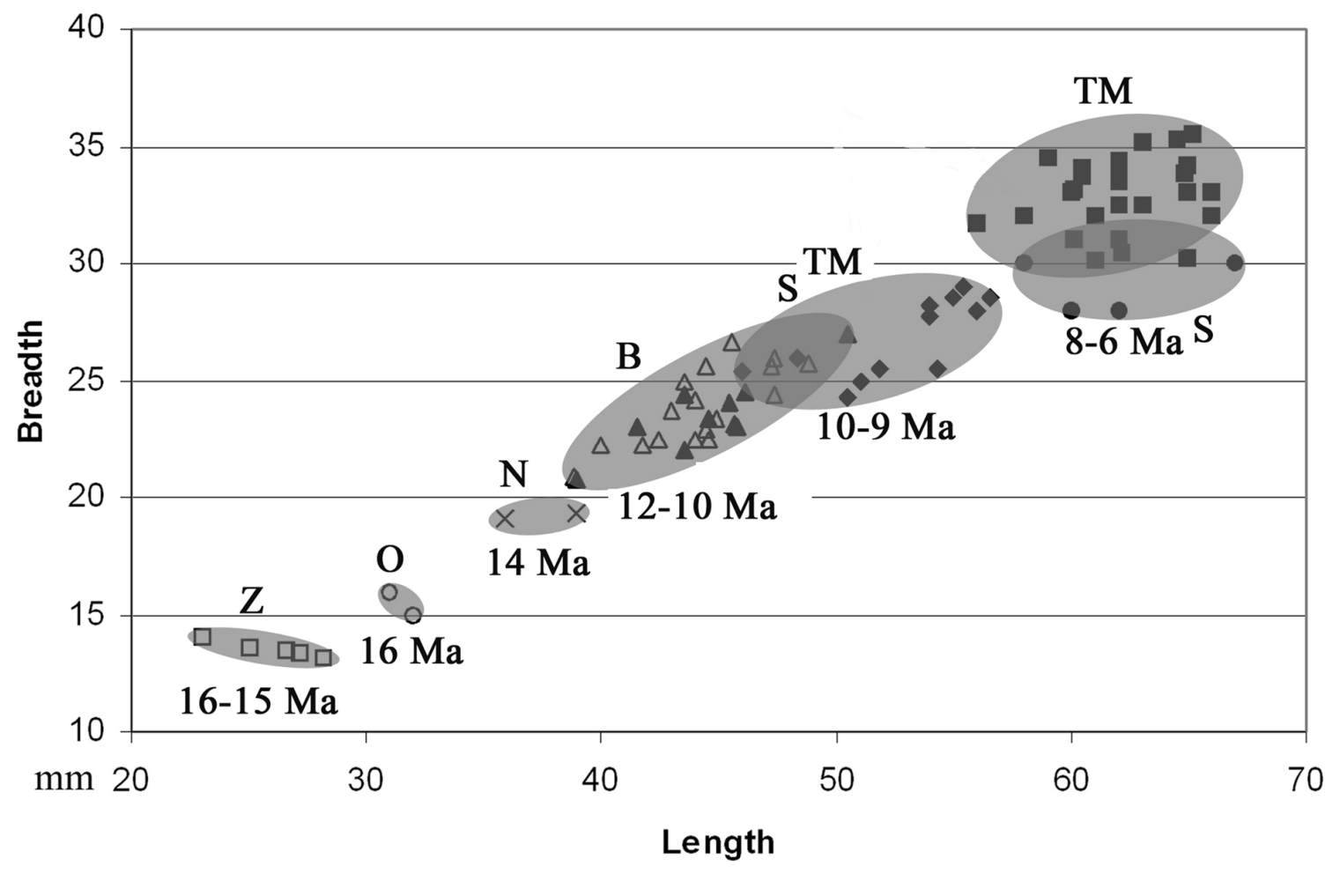

Figure 10. Dimensions of upper and lower third molars of African tetracuspidate anthracotheres and estimated ages of size groups. (B - Beglia, N - Nementcha, O - Ombo, S - Sahabi, TM - Toros-Menalla, Z - Zelten). 
expected for metric variation in a single species of mammal, especially large mammals of the dimensions of anthracotheres. The available sample, even though restricted, indicates the likely presence of two taxa, rather than two sexes of a single species.

When pooled into a single species the measurements of the anthracothere metapodials from Chad show an extremely large range of variation (Table 1) even though the quantity of material is low. Ranges of variation of pooled samples of bones generally exceed $12.5 \%$ and go as high as $16.5 \%$, but when separated into two groups the variation is in most cases a more reasonable figure of less than $11.7 \%$.

\section{HIATUS IN THE CHAD MIOCENE RECORD}

The tempo and mode of evolution has been a matter of investigation for more than a century (Simpson, 1944). The presence of morphological or metric gaps in the fossil record has been interpreted in many ways, including varying rates of evolution (bradytely versus tachytely), gaps in the stratigraphic record, shifts in biogeographic ranges of species and others. For lineages that survived for long periods within a restricted biogeographic province, such as North and Central Africa (Algeria, Tunisia, Libya, Chad) it is unlikely that shifting species ranges could account for abrupt changes in metric variation. In the case of the tetracuspidate anthracotheres of North Africa, the rate of evolution seems to have been quite steady, without abrupt periods of accelerated change interspersed with periods of stagnation (Figs 10,11). The locality sample is small, yet the pattern of metric change seems to be clear; there was an increase in dimensions of this lineage throughout the period 16-6 Ma. The large gap in dimensions between Afromeryx zelteni Pickford, 1991 and Libycosaurus petrocchii Bonarelli, 1947 reflects the presence of a hiatus in the fossil record extending over about 4 million years. This gap is partly filled by Libycosaurus "algeriensis" Ducrocq et al., 2001, from Nementcha, Algeria, but this species is poorly known, and was considered to be a synonym of the Beglia species Libycosaurus anisae (Black, 1972) by Pickford (2006b). The interesting point about the Nementcha occurrence is that it falls into the small end of the range of variation of L. anisae, and it is thought to be from older deposits (Ducrocq et al., 2001), thereby con-

Table 1. Ranges of metric variation of the anthracothere metapodials from Chad.

\begin{tabular}{|c|c|c|c|c|c|c|}
\hline Species Chad & Bone & $\mathbf{N}$ & Minimum length & Maximum length & Minimum distal breadth & Maximum distal breadth \\
\hline \multirow[t]{2}{*}{ Large } & MC III & 5 & 108.4 & 130.3 & 40 & 46.7 \\
\hline & & & Max/Min $\%$ & $12 \%$ & & $11.6 \%$ \\
\hline \multirow[t]{2}{*}{ Medium } & MC III & 5 & 87.5 & 98.3 & 30.8 & 36.2 \\
\hline & & & $\operatorname{Max} / \operatorname{Min} \%$ & $11.2 \%$ & & $11.7 \%$ \\
\hline \multirow[t]{2}{*}{ Pooled } & MC III & 10 & 87.5 & 130.3 & 30.8 & 46.7 \\
\hline & & & Max/Min pooled \% & $14.9 \%$ & & $12.9 \%$ \\
\hline \multirow[t]{2}{*}{ Large } & MC IV & 2 & 137.5 & 137.5 & 47.8 & 55.6 \\
\hline & & & Max/Min\% & -- & & $11.6 \%$ \\
\hline \multirow[t]{2}{*}{ Medium } & MC IV & 1 & 88.9 & 88.9 & 33.7 & 33.7 \\
\hline & & & Max/Min\% & -- & & -- \\
\hline \multirow[t]{2}{*}{ Pooled } & MC IV & 3 & 88.9 & 137.5 & 33.7 & 55.6 \\
\hline & & & Max/Min pooled \% & $15.5 \%$ & & $16.5 \%$ \\
\hline \multirow[t]{2}{*}{ Large } & MT III & 2 & 156 & 158 & 57.3 & 68 \\
\hline & & & Max/Min\% & -- & & $15.1 \%$ \\
\hline \multirow[t]{2}{*}{ Medium } & MT III & 3 & 113.6 & 125 & 45 & 50.2 \\
\hline & & & Max/Min\% & $11 \%$ & & $11.2 \%$ \\
\hline \multirow[t]{2}{*}{ Pooled } & MT III & 5 & 113.6 & 158 & 45 & 68 \\
\hline & & & Max/Min pooled \% & $13.9 \%$ & & $15.1 \%$ \\
\hline \multirow[t]{2}{*}{ Large } & MT IV & 3 & 146.9 & 151.3 & 55.8 & 60.5 \\
\hline & & & Max/Min\% & $10.3 \%$ & & $10.8 \%$ \\
\hline \multirow[t]{2}{*}{ Medium } & MT IV & 2 & 121.1 & 123.4 & 45 & 49.1 \\
\hline & & & Max/Min $\%$ & $10.2 \%$ & & $10.9 \%$ \\
\hline \multirow[t]{2}{*}{ Pooled } & MT IV & 5 & 121.1 & 151.3 & 45 & 60.5 \\
\hline & & & Max/Min pooled \% & $12.5 \%$ & & $13.4 \%$ \\
\hline
\end{tabular}




\section{Anthracothere talus}

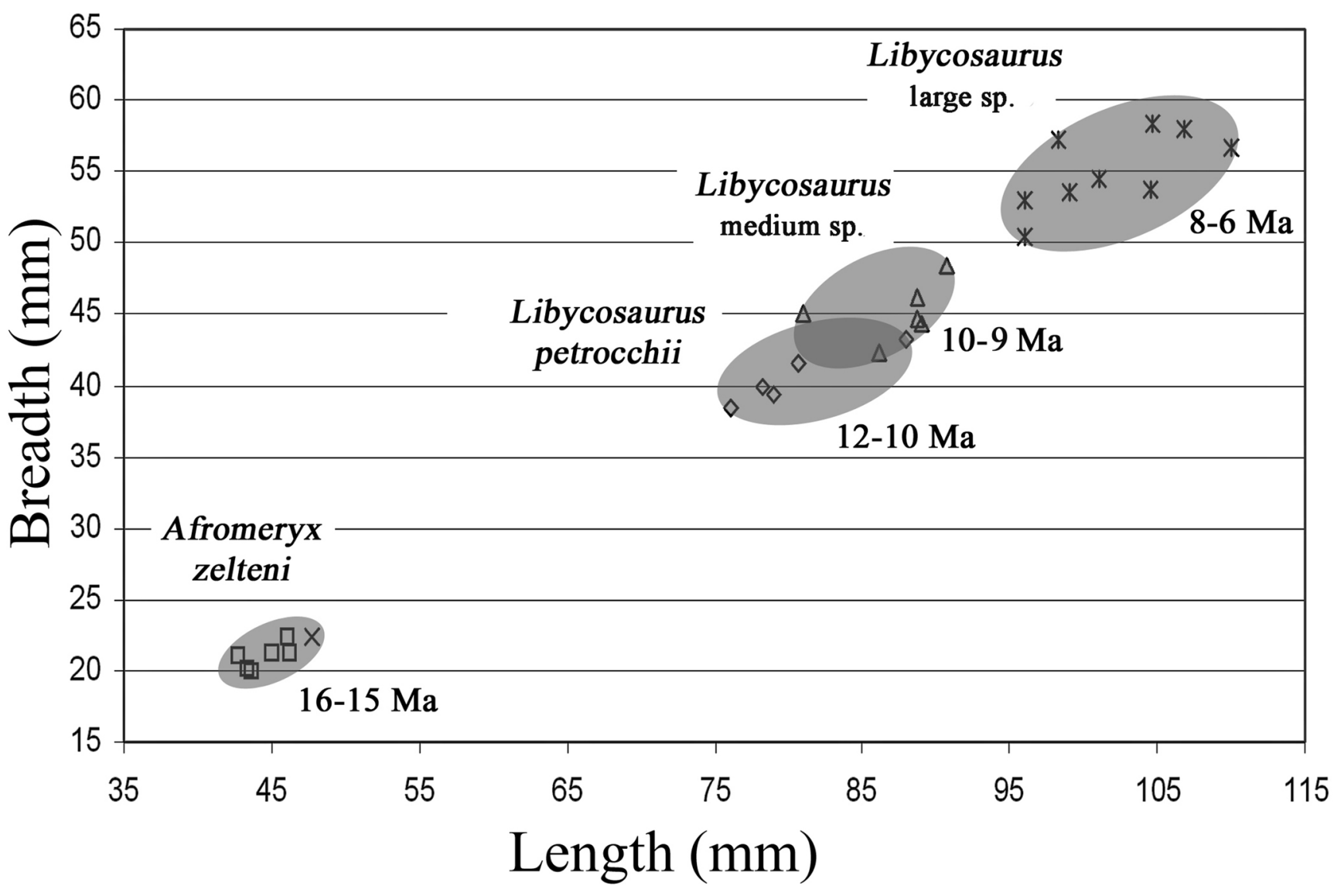

Figure 11. Increase in dimensions of tali of African anthracotheres (Afromeryx and Libycosaurus) with the passage of geological time (squares - Gebel Zelten, Libya; cross - Ombo, Kenya; diamond - Beglia, Tunisia; triangle - Toros Menalla, Chad; cross with vertical bar - Toros Menalla, Chad). Chad data from Lihoreau (2003), other data from Pickford (2006b, 2008b). Pooling the Chad sample into a single species would not only make the species unique in its style of dimorphism, but also in its enormous range of metric variation.

forming to the hypothesis of a lineage that was increasing in body size through its history.

The overlap in the range of metric variation between Libycosaurus from Beglia, Tunisia, and the medium sized species from Chad, suggests that the latter species is marginally younger than the Beglia one, with only a minor time gap between them. In contrast, the lack of overlap in the metric variation of the medium and large anthracotheres from Chad, suggest the presence of a hiatus in the fossil record of the Toros-Menalla (TM) region. The TM fossils have generally been correlated to the Late Miocene ca $7 \mathrm{Ma}$ on the basis of the mammalian fauna (Vignaud et al., 2002). The gap in sedimentation in the Chad Basin could well be about 1 million years, spanning the period 9-8 Ma (Fig. 10).

\section{CONCLUSIONS}

The evidence concerning the biochronology of anthracotheres from the Miocene of Africa based on dimensions of the molars and talus is summarised in figures 10 and 11 . Similar diagrams could be prepared for other bones and teeth, and most of them would show similar relationships.

Finally, whether the Chad anthracotheres are attributed to one species or to two, does not alter the probability that the assemblage represents individuals ranging in age from ca $10 \mathrm{Ma}$ to $6 \mathrm{Ma}$. Furthermore, the separation of the material into two non-overlapping groups in bivariate plots, indicates the presence of a hiatus in the Toros-Menalla sedimentary record which lasted for about 1 million years (from ca 9 to ca $8 \mathrm{Ma}$ ). 


\section{ACKNOWLEDGEMENTS}

I would like to thank the curators of fossil collections at the Natural History Museum, London (Andy Currant), the Département Histoire de la Terre du Muséum National d'Histoire Naturelle, Paris (Claire Sagne) and the Geological Survey of Tunisia (Dr Ben Haj Ali) for access to fossils in their care.

\section{REFERENCES}

Barry, J., Behrensmeyer, A. \& Monaghan, M. 1980. A geologic and biostratigraphic framework for Miocene sediments near Khaur Village, Northern Pakistan. Postilla, 183, 1-19.

Barry, J., Morgan, M., Flynn, L., Pilbeam, D., Behrensmeyer, A., Raza, M., Khan, I., Badgley, C., Hicks, J. \& Kelley, J. 2002. Faunal and environmental change in the Late Miocene Siwaliks of Northern Pakistan. Paleobiology Memoirs, 28, 1-72.

Black, C. 1972. A new species of Merycopotamus (Artiodactyla: Anthracotheriidae) from the late Miocene of Tunisia. Notes de Service Géologique Tunisie, 37, 5-39.

Bonarelli, G. 1947. Dinosauro fossile del Sahara Cirenaico. Rivista di Biologia Coloniale, Roma, 8, 23-33.

Cooke, H.B.S. 1976. Suidae from Plio-Pleistocene strata of the Rudolf Basin. In: Earliest Man and Environments in the Lake Rudolf Basin (Eds Y. Coppens, F. Howell, G. Isaac \& R. Leakey). Chicago University Press, Chicago, 251-263.

Cooke, H.B.S. 1978a. Suid evolution and correlation of African hominid localities: an alternative taxonomy. Science, 201, 460-463.

Cooke, H.B.S. 1978b. Plio-Pleistocene Suidae from Hadar, Ethiopia. Kirtlandia, 29, 1-63.

Cooke, H.B.S. 1984. Horses, elephants and pigs as clues in the African later Cainozoic. In: Late Cainozoic Palaeoclimates of the Southern Hemisphere (Ed. J.C. Vogel). Balkema, Rotterdam, 473-482.

Cooke, H.B.S. 1985. Plio-Pleistocene Suidae in relation to African hominid deposits. In: Beden, M., Behrensmeyer, A.K., Boaz, N.T., Bonnefille, R., Brain, C.K., Cooke, B., Coppens, Y., Dechamps, R., Eisenmann, V., Gentry, A., Geraads, D., Gèze, R., Guerin, C., Harris, J., Koeniguer, J.C., Letouzey, R., Petter, G., Vincens, A. \& Vrba, E. L'Environnement des Hominidés au Plio-Pléistocène. Fondation Singer-Polignac, Masson, Paris, 101-117.

Ducrocq, S., Coiffait, B., Coiffait, P.-E., Mahboubi, M. \& Jaeger, J.-J. 2001. The Miocene Anthracotheriidae (Artiodactyla, Mammalia) from the Nementcha, eastern Algeria. Neues Jahrbuch fur Geologie und Paläontologie Mh., 2001, 145-156.

Falconer, H. 1868. Fauna antiqua sivalensis: Description of Plates. Smith, Elder \& Co, London, 421-556.

Falconer, H. \& Cautley, P.T. 1836. Note on the fossil $\mathrm{Hi}$ ppopotamus of the Siwalik Hills. Asiatic Researches, 19, 39-53.

Falconer, H. \& Cautley, P.T. 1847. Fauna antiqua sivalensis. Smith, Elder \& Co, London, Plates.
Gaziry, A.W. 1982. Anthracotheriidae and Hippopotamidae from the Sahabi Formation. Garyounis Scientific Bulletin Special Issue, 4, 63-70.

Gaziry, A.W. 1987. Merycopotamus petrocchii (Artiodactyla, Mammalia) from Sahabi, Libya. In: Neogene Paleontology and Geology of Sahabi (eds N. Boaz et al.). Alan Liss, New York, 287-302.

Haltenorth, T. \& Diller, H. 1988. A Field Guide to the Mammals of Africa Including Madagascar. Collins, London, $400 \mathrm{pp}$.

Harris, J.M. \& White, T.D. 1979. Evolution of Plio-Pleistocene African Suidae. Transactions of the American Philosophical Society, n.s., 69, 1-128.

Lebatard A.-E., Bourlès, D., Duringer, P., Jolivet, M., Braucher, R., Carcaillet, J., Schuster, M., Arnaud, N., Monié, P., Lihoreau, F., Likius, A., Mackaye, H.T., Vignaud, P. \& Brunet, M. 2008. Cosmogenic nuclide dating of Sahelanthropus tchadensis and Australopithecus bahrelghazali: Mio-Pliocene hominids from Chad. Proceedings of the National Academy of Sciences, 105, 3226-3231.

Lihoreau, F. 2003. Systématique et Paléoécologie des Anthracotheriidae (Artiodactyla: Suiformes) du Mio-Pliocène de l'Ancien Monde: implications Paléobiogéographiques. Thèse, University of Poitiers, 395 pp.

Lihoreau, F., Barry, J., Blondel, C. \& Brunet, M. 2004. A new species of Anthracotheriidae, Merycopotamus medioximus, nov. sp. from the Late Miocene of the Potwar Plateau, Pakistan. Comptes Rendus Palevol, 3, 653-662.

Lihoreau, F., Barry, J., Blondel, C., Chaimanee, Y., Jaeger, J.-J. \& Brunet, M., 2007. Anatomical revision of the genus Merycopotamus (Artiodactyla; Anthracotheriidae): its significance for Late Miocene mammal dispersal in Asia. Palaeontology, 50, 503-524.

Maglio, V.J. 1973. Origin and evolution of the Elephantidae. Transactions of the American Philosophical Society, 63, 1-149.

Pavlakis, P. \& Boaz, N. 2008. Newly discovered remains of As Sahabi Anthracotheriidae. Garyounis Scientific Bulletin, Special Issue, 5, 189-204.

Pickford, M. 1991. Revision of the Neogene Anthracotheriidae of Africa. In: The Geology of Libya (ed. M. J. Salem). Elsevier, Amsterdam, 4, 1491-1525.

Pickford, M. 2006a. Synopsis of the biochronology of African Neogene and Quaternary Suiformes. Transactions of the Royal Society of South Africa, 61, 51-62.

Pickford, M. 2006b. Sexual and individual morphometric variation in Libycosaurus (Mammalia, Anthracotheriidae) from the Maghreb and Libya. Geobios, 39, 267-310.

Pickford, M. 2007. Suidae and Hippopotamidae from the Middle Miocene of Kipsaraman, Kenya, and other sites in East Africa. Paleontological Research, 11, 85-105

Pickford, M. 2008a. Libycosaurus petrocchii Bonarelli, 1947, and Libycosaurus anisae (Black, 1972) (Anthracotheriidae, Mammalia): nomenclatural and geochronological implications. Annales de Paléontologie, 94, 39-55.

Pickford, M., 2008b. The myth of the hippo-like anthracothere: The eternal problem of homology and convergence. Revista Española de Paleontología, 23, 31-90. 
Pickford, M., Moya Sola, S. \& Mein, P. 1997. A revised phylogeny of Hyracoidea (Mammalia) based on new specimens of Pliohyracidae from Africa and Europe. Neues Jahrbuch fur Geologie und Paläontologie Abh., 205, 265-288.

Simpson, G.G. 1944. Tempo and Mode in Evolution. Columbia University Press, New York, 237 pp.

Vignaud, P., Duringer, P., Mackaye, H.T., Likius, A., Blondel, C., Boisserie, J.-R., de Bonis, L., Eisenmann, V., Etienne,
M.E., Geraads, D., Guy, F., Lehmann, T., Lihoreau, F., Lopez-Martinez, N., Mourer-Chauviré, C., Otero, O., Rage, J.-C., Schuster, M., Viriot, L., Zazzo, A. \& Brunet, M. 2002. Geology and palaeontology of the upper Miocene Toros-Menalla hominid locality. Nature, 418, 152-155.

Manuscrito recibido: 7 de Octubre, 2008 Manuscrito aceptado: 1 de Septiembre, 2009 